\title{
INTENSITAS PENILAIAN FORMATIF DALAM PEMBELAJARAN KALKULUS DENGAN MENGENDALIKAN KEMAMPUAN AWAL MAHASISWA
}

\author{
SUPARDI U.S. \\ supardi@unindra.ac.id \\ Program Studi Pendidikan Matematika, Fakultas Teknik, Matematika dan Ilmu Pengetahuan Alam \\ Universitas Indraprasta PGRI (UNINDRA), \\ Tanjung Barat, Jagakarsa, Jakarta Selatan
}

\begin{abstract}
The objective of the study was to know the effects of formative assessment intensity toward Calculus learning outcomes with controlling university students' prior capacity. Research using experimental methods, and can be concluded from the finding, that with controlling university students' prior capacity, the group was given formative assessment each subject matter got higher score on Calculus learning outcomes than the group was given conventional formative assessment. The result showed that there was formative assessment intensity has effect toward Calculus learning outcomes with controlling university students' prior capacity. To improve the quality of Calculus learning outcomes, the lecturers were supposed to evaluate the university stuents' the better using formative assessment intensity each subject matter.
\end{abstract}

Key words: formative assessment intensity, calculus learning outcomes, university students' prior capacity, analysis of covarian.

\section{PENDAHULUAN}

Lulusan dari suatu jenjang pendidikan harus bermutu dan kompetitif. Sholeh (2005: 34) mengatakan, "Peningkatan mutu pendidikan merupakan suatu langkah yang dilakukan secara terencana, yang mencakup dua strategi. Pertama, merupakan perencanaan jangka pendek untuk meningkatkan kemampuan intelektual peserta didik sebagai standar minimal untuk meraih tujuan pendidikan jangka panjang yang mengacu pada pengembangan manusia Indonesia seutuhnya. Kedua, adalah strategi jangka panjang yang mengarah ke tujuan pendidikan berlandasan luas, bermanfaat, nyata, dan bermakna dalam mempersiapkan peserta didik menghadapi tantangan masa depan." Pendidikan bermutu adalah pendidikan yang dapat menghasilkan sumber daya manusia seutuhnya yang handal lahir maupun batin serta bermakna.

Seiring dengan peningkatan kuantitas, maka upaya untuk menjaga dan meningkatkan kualitas proses pembelajaran merupakan suatu keniscayaan yang perlu terus digalakan dan dikembangkan. Walija (2007: 1-16) mengatakan, lembaga-lembaga pendidikan yang tidak berkualitas lama kelamaan akan ditinggalkan orang dan tersingkir dengan sendirinya. Dia tidak akan mampu bertahan. Berkualitas di sini mencakup berbagai bidang misalnya (1) berkualitas dalam bidang pembelajaran, (2) berkualitas dalam bidang pelayanan, dan (3) berkualitas dalam bidang sarana prasarana yang disediakan. Peningkatan mutu pendidikan di antaranya dilakukan melalui upaya-upaya perbaikan proses pembelajaran dengan menggunakan berbagai metode pembelajaran dan inovasi penilaian formatif. Untuk itu, dosen sebagai agen pembelajaran pada perguruan tinggi di samping menguasai kompetensi bidang keilmuannya harus juga menguasai berbagai metode pembelajaran maupun hal-hal yang terkait dengan inovasi penilaian formatif. Melalui penguasaan berbagai metode dan inovasi penilaian formatif maka 
proses pembelajaran dapat dilakukan secara bervariasi disesuaikan dengan karakteristik atau kondisi internal mahasiswa sehingga akan menghasilkan lulusan yang berkualitas.

Secara garis besar bidang ilmu matematika terdiri atas beberapa kelompok bidang/cabang ilmu. Ibrahim Abdullah (2006: 3) dalam makalah orasi ilmiah berjudul Matematika sebagai Dasar Semua Ilmu mengemukakan: "Asosiasi Matematikawan se dunia mengelompokkan matematika menjadi 10 cabang: Aritmatika, Aljabar, Geometri, Trigonometri, Kalkulus, Probabilitas dan Statistik, teori set dan logic, Teori Angka, Analisys system, dan teori Chaos". Kalkulus merupakan salah satu dari matematika memiliki peran yang strategis dalam perkembangan teknologi dan bidang-bidang ilmu lain

Dalam pandangan dan persepsi mahasiswa, masih banyak didapat yang menganggap bahwa kalkulus merupakan pelajaran yang sulit. Bahkan pada tataran pendidikan dasar dan menengah pun masih banyak didapati peserta didik yang menganggap matematika merupakan pelajaran yang sulit dan tidak menarik. Dampak dari persepsi ini mengakibatkan sebagian peserta didik tidak dapat fokus dan juga tidak mampu mendapatkan strategi belajar yang tepat, sehingga berakibat pada tingkat penguasaan konsep kalkulus atau matematika yang rendah. Fenomena ini tergambar dari perolehan hasil belajar kalkulus mahasiswa yang relatif rendah jika dibandingkan dengan rerata hasil belajar mata kuliah lainnya. Rendahnya penguasaan konsep matakuliah kalkulus akan mengakibatkan mahasiswa menjadi terhambat dalam pembelajaran matakuliah-matakuliah berikutnya, khususya pada matakuliah yang menjadikan kalkulus sebagai pengetahuan prasyarat, seperti persamaan diferensial, fisika dasar, analisa real, vektor, dan lain-lain. Padahal Buchori (2001: 121-122) mengatakan, "Kalau kita betulbetul ingin meningkatkan kemampuan bangsa di bidang teknologi di masa depan, maka tidak boleh dibiarkan adanya anak-anak muda yang buta matematika (mathematically illiterate) dan buta ilmu pengetahuan alam (scientifically illiterate). Suatu masyarakat hanya akan berhasil mengembangkan kemampuan teknologi yang cukup tinggi kalau dalam masyarakat tadi terdapat lapisan-lapisan penduduk dengan tingkat pemahaman tentang matematika dan ilmu pengetahuan alam yang beragam, dari kemampuan yang bersifat keahlian sampai ke pemahaman yang bersifat apresiatif."

Konsep-konsep kalkulus berperan penting dalam pengembangan ilmu-ilmu bidang eksakta. Purwanto dkk (2005: 7) mengemukakan, Kalkulus merupakan suatu alat bantu dalam dunia ilmu pengetahuan untuk menguraikan perubahan. Kalkulus sebagai alat yang digunakan dalam berbagai bidang kehidupan. Hampir semua bidang ilmu rekayasa seperti Teknik Elektro, Teknik Mesin, Teknik Sipil, Teknik Industri, Teknik Arsitektur dan lain-lain dalam pengembangannya menggunakan konsep kalkulus. Demikian pun halnya untuk bidang-bidang ilmu eksakta lainnya seperti pertanian, kedokteran, farmasi dan lain-lain memerlukan konsep kalkulus dalam pengembangan ilmunya. Bahkan untuk bidang-bidang ilmu sosial seperti ekonomi, psikologi, dan lainnya juga memerlukan konsep kalkulus.

Upaya peningkatan kualitas hasil belajar kalkulus ini, harus diimbangi dengan kompetensi para dosen, yaitu kemampuan untuk mengajar dan juga kemampuan dalam inovasi intensitas penilaian formatif. Intensitas penilaian formatif yang dikembangkan dalam penelitian ini adalah Intensitas Penilaian Formatif Per Pokok Bahasan yang lebih intensif dan Intensitas Penilaian Formatif Keseluruhan seperti yang berlangsung dewasa ini (konvensional). Intensitas Penilaian Formatif Per Pokok Bahasan, yaitu suatu cara pemberian penilaian formatif dilakukan melalui proses penilaian setelah suatu materi pokok bahasan tertentu selesai diajarkan dalam 1 (satu) atau beberapa kali pertemuan. Sementara, Intensitas Penilaian Formatif Keseluruhan (konvensional), yaitu suatu cara 
pemberian penialain yang dilakukan setelah semua materi pelajaran selesai dibelajarkan secara keseluruhan, tidak didasarkan atas suatu pokok bahasan tertentu.

Intensitas penilaian formatif yang digunakan selama ini secara konvensional cenderung menggunakan Intensitas Penilaian Formatif Keseluruhan, sehingga mahasiswa kurang terbiasa menghadapi tes per materi (per pokok bahasan) dan dilakukan remedial lebih sering. Kondisi ini diharapkan dapat diubah, mengingat untuk mencapai kedewasaan dan kematangan seseorang harus dapat mengadaptasi berbagai macam perubahan yang terjadi dalam kehidupannya.

Faktor lain yang juga mempengaruhi hasil belajar kalkulus adalah kemampuan awal mahasiswa. Hal ini mutlak dan tidak bisa ditawar-tawar lagi, mengingat dengan memiliki kemampuan awal yang baik, mahasiswa mampu mengikuti proses pembelajaran dengan baik, sehingga akan mendapatkan hasil belajar yang baik pula. Kemampuan awal merupakan bahan dasar yang dimiliki oleh seseorang, yang dapat diolah kembali untuk menghasilkan hal lainnya. Kemampuan awal dalam penelitian ini adalah hasil belajar mahasiswa dalam mata kuliah sebelumnya, yang masih berhubungan dengan mata kuliah selanjutnya. Dalam penelitian ini dibahas materi kuliah Kalkulus Dua (Kalkulus Integral), maka kemampuan awal mahasiswanya adalah hasil belajar dalam matakuliah Kalkulus Satu (Kalkulus Diferensial).

Berdasarkan permasalahan yang terungkap dalam paparan di atas

maka masalah yang diteliti dalam penelitian ini dirumuskan sebagai berikut: (1) Dengan mengontrol pengaruh kemampuan awal, adakah perbedaan hasil belajar kalkulus antara mahasiswa yang diberikan Intensitas Penilaian Formatif Per Pokok Bahasan dan Intensitas Penilaian Formatif Konvensional (Keseluruhan)? (2) Manakah hasl belajar Kalkulus yang lebih tinggi antara yang diberikan Intensitas Penilaian Formatif Per Pokok Bahasan dengan yang diberikan Intensitas Penilaian Formatif Keseluruhan, apabila pengrauh kemampuan awal mahasiswa dikendalikan?

\section{TINJAUAN PUSTAKA \\ Hasil Belajar Kalkulus}

Hasil belajar adalah pola-pola perubahan tingkah laku seseorang yang meliputi aspek kognitif, afektif dan/atau psikomotor setelah menempuh kegiatan belajar tertentu yang tingkat kualitas perubahannya sangat ditentukan oleh faktor-faktor yang ada dalam diri mahasiswa dan lingkungan sosial yang mempengaruhinya. Jadi intinya dapat dikatakan perubahan tingkah laku merupakan wujud hasil belajar seseorang setelah mempelajari sesuatu objek. Jika objeknya Kalkulus, maka perubahan tingkah laku tersebut yaitu perubahan pengetahuan, sikap, minat, kecenderungan atau tindakan yang terkait dengan Kalkulus. Bentuk-bentuk perubahan dimaksud dapat berupa dari tidak tahu menjadi tahu, dari tidak berminat menjadi berminat, dari tidak cekatan menjadi cekatan dan sebagainya.

Kalkulus merupakan bagian dari ilmu matematika. Kalkulus sangat terkait sebagai diiplin ilmu yang mempelajari tentang diferensial dan integral suatu fungsi. Matematika adalah ilmu yang mempelajari tentang cara penalaran logis yang memiliki nilai praktis, disiplin dan budaya dengan objek berupa ide/konsep abstrak yang tersusun secara hirarkis yang diwujudkan dalam bentuk simbol-simbol serta penalarannya bersifat deduktif. Kakulus merupakan salah satu cabang keilman yang dipelajari dalam matematika.

Hasil belajar Kalkulus dapat diartikan sebagai perwujudan dari proses kerberhasilan pembelajaran Kalkulus yang dicerminkan dengan perubahan tingkah laku dalam bentuk kognitif, afektif maupun psikomotor seseorang setelah mendapatkan pengalaman belajar Kalkulus. Hal ini diperkuat oleh pendapat Dimyati dan Mudjiono 
(2006: 3) yang mengatakan bahwa, hasil belajar merupakan hasil dari suatu interaksi tindak belajar dan tindak mengajar. Mahasiswa bertindak belajar, artinya mengalami proses dan meningkatkan kemampuan mentalnya.

Dari keterangan di atas jelaslah bahwa seseorang yang sudah belajar tidak sama keadaannya dengan ketika belum belajar. Proses pengukuran hasil belajar perlu dilakukan agar dapat dilakukan penilaian yang tepat terhadap perubahan-perubahan perilaku yang dialami mahasiswa. "Penilaian hasil belajar baru dapat dilakukan dengan baik dan benar bila menggunakan informasi yang diperoleh melalui pengukuran hasil belajar (Zainul dan Nasution, 2005: 9)."

Suyatno (2009: 9) mengemukakan bahwa, pembelajaran yang dimulai dari masalah mendorong peserta didik belajar sutu konsep dan prinsip serta sekaligus belajar memecahkan masalah. Dengan demikian, sekurang-kurangnya ada dua hasil belajar yang dicapai, yaitu jawaban terhadap masalah (produk) dan cara memecahkan masalah (proses). Kemampuan memecahkan masalah merupakan hasil belajar yang paling tinggi. Hasil belajar Kalkulus terwujud dari kecakapan seseorang dalam menyelesaikan problema (masalah) yang terkait dengan konsep-konsep Kalkulus. Indikasi kemampuan Kalkulus mahasiswa terwujud dari hasil belajar dan pengalaman belajarnya sebagai indikator pencapaian tujuan pembelajaran Kalkulus. Wena (2009: 14) menyatakan, bahwa dalam proses belajar, tujuan pembelajaran harus ditetapkan terlebih dahulu. Adanya perbedaan tujuan pembelajaran akan berimplikasi pada adanya perbedan pemilihan strategi pembelajaran yang berbeda pula, termasuk didalamnya penilaian formatif dan alat ukur penilaian yang digunakan. Menurut Shaffat (2009: 6-7), bahwa tujuan belajar sangat terkait dengan kemampuan kognitif, afektif dan psikomotorik. Pertama, untuk mendapatkan pengetahuan (acquiring knowledge). Kedua, penanaman konsep dan keterampilan. Ketiga, pembentukan sikap dan prilaku. Jadi sebagai pendidik, guu/dosen tidak hanya menstransfer pengetahuan (transfer of knowledge) tetapi juga harus melakukan penanaman nilai-nilai (transfer of values). Dari pendapat tersebut, menunjukkan bahwa pencapaian tranfer belajar merupakan tujuan utama pengajaran Kalkulus. Sedangkan Kalkulus dalam penelitian ini adalah cabang ilmu matematika yang mempelajari integral satu peubah, yaitu ilmu yang mempelajari tentang tata cara untuk mendapatkan bentuk asal dari sebuah fungsi turunan atau merupakan invers dari Kalkulus Diferensial dari semua bentuk fungsi baik fungsi aljabar maupun fungsi goneometri, yang secara spesifik sebagai materi matakuliah dengan pokok bahasan meliputi: konsep integral tak tentu, teknik-teknik pengintegralan, teknik pengintegralan fungsi khusus, integral tertentu dan integral tak wajar, serta aplikasi integral tertentu yang meliputi beberapa sub pokok bahasan seperti: luas bidang datar, volume benda putar, panjang busur, dan luas selimut benda putar.

Berdasarkan di atas, dapat disimpulkan bahwa hasil belajar Kalkulus adalah pola-pola perubahan tingkah laku mahasiswa sebagai indikator tingkat ketercapaian tujuan belajar Kalkulus dalam penguasaan struktur kognitif berupa fakta-fakta, konsepkonsep dan generalisasi setelah mendapatkan pengalaman belajar dengan materi atau pokok bahasan: konsep integral tak tentu, teknik-teknik pengintegralan, teknik Integral fungsi khusus, integral tertentu \& integral tak wajar, dan aplikasi integral tertentu yang meliputi beberapa sub pokok bahasan seperti: luas bidang datar, volume benda putar, panjang busur kurva, dan luas selimut benda putar.

\section{Intensitas Penilaian Formatif}

Sudah menjadi rahasia umum, bahwa di kalangan mahasiswa, terjadi sistem belajar sks yang diplesetkan, yaitu sks diartikan sebagai cara belajar dengan sistem kebut semalam. Hal ini diartikan sebagai bentuk keaktifan belajar mahasiswa dikarenakan ada 
kegiatan ujian atau tes yang dilakukan di kelas. Kondisi ini sebenarnya dapat dimanfaatkan oleh para dosen di perguruan tinggi, dengan tujuan untuk membentuk kebiasaan mahasiswa agar selalu belajar dan mempersiapkan diri dengan baik setiap harinya.

Pembentukan kebiasaan ini tentu saja tidak bisa terjadi secara instant, akan tetapi dibutuhkan proses dan pembiasaan yang panjang. Mahasiswa yang akan dibentuk kebiasaannya harus bisa dan selalu berpikir bahwa setiap hari akan diadakan penilaian/tes, sehingga secara langsung maupun tidak langsung akan memotivasi dirinya untuk belajar. Dosen yang melakukan penilaian belajar lebih sering dan teratur, tentu akan membuat mahasiswa lebih siap dalam mempelalajari bahan-bahan yang akan dievaluasi dan juga tidak membebani mahasiswa dari kewajiban untuk memahami materi dalam jumlah yang sangat besar sekaligus.

Seperti telah dijelaskan dalam bagian sebelumnya, bahwa penilaian formatif pada dasarnya adalah tes yang bertujuan untuk mendapatkan umpan balik bagi usaha perbaikan kualitas pembelajaran dalam konteks kelas. Atau, jika dikaji lebih jauh, bahwa kualitas pembelajaran di kelas dapat ditingkatkan dengan intensitas penilaian. Kualitas hasil belajar juga ditentukan oleh banyak atau sedikitnya intensitas pelaksanaan penilaian formatif. Hal ini senada dengan yang diungkapkan Djaali dan Muljono (2008: 9), bahwa penilaian formatif yang diselenggarakan dalam selang waktu yang relatif pendek akan memberikan masukan atau umpan balik yang digunakan oleh pendidik sebagai pengelola kegiatan pembelajaran dalam meningkatkan intensitas proses belajar dalam diri setiap subjek belajar melalui peningkatan kesesuaian antara tiga unsur, yaitu strategi kognitif, karakteristik konsep, dan strategi pembelajaran yang digunakan. Pemberian penilaian formatif yang dilakukan setiap topik (pokok bahasan) dapat meningkatkan intensitas belajar mahasiswa. Oleh karenanya, sebaiknya setiap akhir pokok bahasan perlu diberikan penilaian formatif, yang berguna untuk melakukan modifikasi pembelajaran agar pencapaian ketuntatasan belajar (mastery) mahasiswa dapat diketahui lebih awal.

Rose dan Nicholl (1997: 142) mengatakan hal yang berkaitan dengan daya ingat dan jenis aktivitas belajar yaitu: "The more you can see it, hear it, say it, and do it, the easier it is to learn. It has been said that, on average, we remember: $20 \%$ of what we read, $30 \%$ of what we hear, $40 \%$ of what we see, $50 \%$ of what we say, $60 \%$ of what we do, $90 \%$ of what we see, hear, say, and do". Semakin banyak Anda dapat melihat, mendengar, mengatakan, dan melakukan sesuatu, semakin mudah sesuatu dipelajari. Rata-rata manusia dapat mengingat: (1) 20\% dari yang dibaca, (2) 30\% dari yang didengar, (3) $40 \%$ dari yang dilihat, (4) 50\% dari yang dikatakan, (5) 60\% dari yang dikerjakan, dan (6) 90\% dari yang dilihat, didengar, dikatakan, dan dikerjakan sekaligus. Jadi daya ingat akan kuat, jika dalam belajar mengaktifkan seluruh indra yang dimiliki dan dilakukan lebih sering (intensitas tinggi).

Santrock (2007: 320) mengatakan, bahwa sistem memori manusia memiliki kapasitas terbatas, sehingga informasi tidak dapat bertahan lama, dan perlu dilakukan pengulangan agar dapat tersimpan lebih lama. Pengulangan dapat dilakukan atas inisiatif mahasiswa atau dapat juga dirancang oleh dosen. Pengulangan yang dilakukan atas inisiatif mahasiswa, merupakan sesuatu yang sangat jarang terjadi. Untuk itu, pengulangan belajar sebaiknya dirancang oleh dosen. Pengulangan belajar dapat berupa pemberian PR, tugas harian dan atau penilaian formatif. Artinya, semakin sering dilakukan pengulangan, baik berupa PR (pekerjaan rumah), tugas harian dan atau penilaian formatif, maka pemahaman mahasiswa pada materi yang diajarkan akan semakin tinggi. McMillan dalam Santrock (2007: 638) menyatakan bahwa, pendidik yang kompeten sering melakukan evaluasi (penilaian) muridnya dalam konteks tujuan pembelajaran. 
Purwanto (2007: 102-103) menjelaskan bahwa salah satu faktor yang mempengaruhi hasil belajar peserta didik yaitu tingkat intensitas latihan dan ulangan. Karena sering mengulangi sesuatu materi pelajaran, maka kecakapan dan pengetahuan yang dimilikinya dapat menjadi semakin dikuasai dan mendalam. Sebaliknya bahwa tanpa latihan dan pengulangan yang memadai, maka pengalaman-pengalaman yang telah dimilikinya dapat menjadi hilang atau berkurang.

Berapa kalikah idealnya penilaian formatif dilakukan dalam satu semester? Surapranata (2007: 29) mengatakan, bahwa tidak ada aturan umum yang menyatakan banyaknya intensitas dosen harus memberikan penilaian formatif kepada peserta didik. Tetapi dalam hal ini yang menjadi patokan penting adalah pencapaian tujuan (standar kompetensi, kompetensi dasar, dan indikator) yang termuat dalam kurikulum. Namun, jika dosen mengembangkan lima satuan pelajaran dalam satu semester misalnya, maka paling tidak dosen sebaiknya melakukan enam kali penilaian atau tes. Lima kali tes yang pertama dikenal dengan penilaian formatif (ulangan harian) digunakan untuk melihat pencapaian tujuan pembelajaran yang telah ditetapkan dalam lima satuan pelajaran, dan satu kali tes dilakukan pada akhir semester yang dikenal juga sebagai penilaian sumatif (ujian akhir semester).

Dari uraian di atas, maka dapat dikatakan bahwa intensitas penilaian formatif adalah tingkat kekerapan atau banyaknya kegiatan penilaian formatif yang dilakukan oleh dosen dalam rangka mendapatkan informasi yang terkait dengan efektifitas proses dan peningkatan kualitas hasil belajar. Dalam penelitian ini intensitas penilaian formatif terdiri atas dua kategori yaitu: Intensitas Penilaian Formatif Per Pokok Bahasan dan Intensitas Penilaian Formatif Konvensional (keseluruhan).

\section{Kemampuan Awal Kalkulus}

Menurut Al-Kadiri (2009), kemampuan awal adalah kemampuan yang telah dipunyai oleh peserta didik sebelum mengikuti pembelajaran yang akan diberikan. Kemampuan awal ini menggambarkan kesiapan peserta didik dalam menerima pelajaran yang akan disampaikan atau pengetahuan yang merupakan prasyarat untuk mengikuti pembelajaran. Sedangkan Supardi U.S. dan Simangunsong (2009: 70) berpendapat, bahwa kemampuan belajar adalah kemampuan dasar yang dimiliki oleh seorang mahasiswa sebelum mahasiswa tersebut mengikuti proses pendidikan pada tahap yang lebih tinggi. Kemampuan awal juga merupakan tingkat kesiapan belajar yang dimiliki mahasiswa sebelum mengikuti proses pembelajaran. Hal ini seperti disampaikan pula oleh Pidarta (2007: 229), "Kesiapan belajar secara umum adalah kemampuan seseorang untuk mendapatkan keuntungan dari pengalaman yang ia temukan. Sementara itu kesiapan kognisi bertalian dengan pengetahuan, pikiran dan kualitas berpikir seseorang dalam menghadapi situasi belajar yang baru."

Setiap mahasiswa telah mempunyai berbagai kemampuan dasar dalam bentuk pengalaman, kondisi dan potensi sewaktu memasuki situasi belajar. Mahasiswa telah memiliki sikap-sikap dan intelegensi tertentu serta pengalaman belajar sebelumnya yang diperoleh dari dalam maupun di luar kampus. Semuanya ini merupakan latar belakang ataupun kemampuan awal dan karakteristik mahasiswa. Pengetahuan atau kemampuan yang telah dimiliki mahasiswa yang berhubungan dengan pelajaran yang akan diikutinya memegang peranan penting dalam proses belajar mengajar di kampus. Informasi ini perlu diketahui dosen. Dengan hal ini, dosen dapat merancang dan mendesain model pembelajaran secara tepat dan berarti. Untuk dapat merancang pembelajaran yang efektif, seorang dosen harus mampu mengidentifikasi kemampuan awal mahasiswa sehingga mempunyai implikasi pada perencanaan model pembelajaran. Oleh sebab itu, mengenali tingkah laku masukan (intake behavior) dan ciri-ciri 
mahasiswa merupakan langkah awal yang sangat penting dan berguna dalam memperjelas sasaran pembelajaran.

Pengaruh kemampuan awal akan tampak dalam pemantauan hasil belajar mahasiswa dalam jangka waktu tertentu. Sebab pada umumnya hasil belajar mahasiswa yang dicantumkan sebagai skor hasil studi dalam suatu matakuliah tertentu dapat memprediksi perkembangan hasil belajar dalam satu, dua atau tiga semester berikutnya. Dengan demikian, perilaku kemampuan awal mempunyai dua karakteristik, yaitu : (1) sebagai prasyarat belajar untuk menghadapi pelajaran berikutnya, dan (2) mempunyai hubungan dengan hasil belajar dalam materi dan tugas-tugas pembelajaran berikutnya. Rasyad (2003: 103) menyatakan, bahwa hasil belajar yang dicapai mahasiswa dipengaruhi oleh dua faktor utama yaitu faktor dari dalam diri mahasiswa dan faktor dari luar atau lingkungan. Faktor yang datang dari dalam diri mahasiswa terutama kemampuan awal yang dimilikinya. Faktor kemampuan awal besar sekali pengaruhnya terhadap hasil belajar yang dicapai.

Mahasiswa memiliki kemampuan dasar yang dapat dipengaruhi oleh dua faktor yaitu faktor internal (hereditas) dan faktor eksternal (lingkungan pendidikan). Berkaitan dengan kemampuan awal mahasiswa, yaitu apabila mahasiswa mempunyai kemampuan dasar yang baik maka perkembangan selanjutnya akan mengarah kepada keberhasilan. Jika hal ini dianalogikan terhadap proses belajar-mengajar maka dengan adanya kemampuan awal yang baik maka mahasiswa akan memperoleh hasil yang baik pula. Untuk mendapatkan hasil belajar yang baik maka kemampuan awal mahasiswa juga harus baik. Kemampuan awal yang dimiliki mahasiswa dapat diketahui apabila telah dilakukan pengukuran dan penilaian pada mahasiswa sebelum proses pembelajaran. Berdasarkan paparan di atas maka dapat disimpulkan bahwa kemampuan awal adalah pegetahuan dasar yang dimiliki oleh seorang mahasiswa sebelum mengikuti proses pembelajaran matakuliah berikutnya yang materi ajarnya memiliki saling keterpautan.

Kalkulus dalam penelitian ini adalah cabang ilmu matematika yang terkait dengan integral fungsi satu peubah sebagai ilmu yang mempelajari tentang tata cara untuk mendapatkan bentuk asal dari sebuah fungsi turunan atau merupakan invers dari Kalkulus diferensial, yang secara spesifik sebagai materi matakuliah Kalkulus integral dengan pokok bahasan meliputi: konsep integral tak kentu, teknik-teknik pengintegralan, integral fungsi khusus, integral tertentu \& integral tak wajar, dan aplikasi inegral tertentu yang meliputi beberapa sub pokok bahasan seperti: luas bidang datar, volume benda putar, panjang busur, dan luas selimut benda putar.

Kemampuan awal adalah pegetahuan dasar yang dimiliki oleh seorang mahasiswa sebelum mengikuti proses pembelajaran matakuliah berikutnya yang materi ajarnya memiliki saling keterpautan. Sehingga pengetahuan prasyarat untuk mengikuti Kalkulus integral yaitu Kalkulus diferensial. Oleh karena itu, penguasaan terhadap konsep-konsep Kalkulus diferensial merupakan kemampuan awal bagi mahasiswa yang hendak mengikuti pembelajaran Kalkulus integral.

Dalam Kalkulus diferensial, secara garis besar mempelajari tentang tata cara menentukan turunan atau derivatif dari suatu fungsi. Dalam implementasi dunia empirik dari konsep Kalkulus diferensial ini, seperti ilustrasi permasalahan tentang seorang pembalap yang ingin mengetahui laju kecepatannya pada suatu waktu tertentu. Laju perubahan ini semuanya merupakan kasus khusus dari gagasan matematika tunggal, yakni turunan fungsi yang dipelajari dalam Kalkulus diferensial. Fenomena ini juga sekaligus sebagai prasyarat pengetahuan untuk mengikuti pembelajaran Kalkulus integral.

Kalkulus diferensial berkenaan dengan bagaimana suatu besaran berubah dalam hubungannya dengan besaran lain. Konsep utama dari Kalkulus diferensial adalah turunan, yang merupakan perkembangan dari kecepatan dan kemiringan garis singgung 
(Stewart: 2001: 146). Kalkulus diferensial merupakan matakuliah dasar, walaupun untuk mempelajarinya diperlukan beberapa pengetahuan prasyarat yang harus dikuasai, yaitu Aljabar dan Trigonometri. Secara spesifik, materi atau pokok bahasan yang harus dipelajari dalam Kalkulus Satu (Kalkulus diferensial) meliputi: 1) bilangan real \& fungsi, 2) limit fungsi \& kontinuitas, 3) konsep turunan \& jenis-jenis atau teknik-teknik turunan fungsi yang meliputi: turunan fungsi berantai, turunan fungsi tingkat tinggi, turunan fungsi parameter, turunan fungsi implisit, dan turunan fungsi pangkat fungsi; 4) bentuk tak tentu dan dalil L'Hospital; serta 5) aplikasi turunan yang melputi beberapa sub pokok bahasan seperti: titik ekstrim dan kemonotonan fungsi, maksimum/minimum dalam permasalahan matematika, maksimum/minimum dalam permasalahan praxis keseharian, serta garis singgung dan garis normal.

Berdasarkan paparan di atas, dapat disimpulkan bahwa kemampuan awal Kalkulus adalah pengetahuan atau potensi kognitif yang dimiliki seorang mahasiswa yang melandasi keilmuan yang akan dipelajarinya sebelum mahasiswa tersebut mengikuti pembelajaran Kalkulus integral. Potensi kognitif dimaksud merupakan penguasaan konsep-konsep Kalkulus diferensial sebagai landasan dari Kalkulus integral yang akan dipelajari, yaitu meliputi konsep-konsep materi: bilangan real \& fungsi, limit fungsi \& kontinuitas, konsep turunan \& jenis-jenis atau teknik-teknik turunan fungsi (meliputi: turunan fungsi berantai, turunan fungsi tingkat tinggi, turunan fungsi parameter, turunan fungsi implisit, dan turunan fungsi pangkat fungsi); bentuk tak tentu dan dalil L'Hospital; serta aplikasi turunan yang melputi beberapa sub pokok bahasan seperti: titik ekstrim dan kemonotonan fungsi, maksimum/minimum dalam permasalahan matematika, maksimum/minimum dalam permasalahan praxis keseharian, serta garis singgung dan garis normal.

\section{METODE PENELITIAN}

Penelitian ini dilakukan dengan pendekatan kuantitatif, menggunakan metode penelitian eksperimen. Secara spesifik penelitian eksperimen ini menggunakan teknik quasi eksperiment atau eksperimen lapangan. Penelitian ini menempatkan hasil belajar Kalkulus dengan skala data numerik sebagai variabel terikat (criterion variable), intensitas penilaian formatif (treatment variable) sebagai variabel bebas perlakuan, dan kemampuan awal Kalkulus dengan skala data numerik sebagai variabel bebas kovariat. Eksperimen ini menggunakan desain analisis kovarian (ANKOVA) treatment by level $2 \times 2$ seperti berikut.

Tabel 1. Desain Penelitian

\begin{tabular}{|c|c|}
\hline \multicolumn{2}{|c|}{ Intensitas penilaian formatif $(\boldsymbol{A})$} \\
\hline $\boldsymbol{A}_{\boldsymbol{I}}$ & $\boldsymbol{A}_{\mathbf{2}}$ \\
\hline$[X, Y]_{11 k}$ & {$[X, Y]_{12 k}$} \\
$k=1,2, \ldots, n_{11}$ & $k=1,2, \ldots, n_{12}$ \\
\hline$[X, Y]_{2 l k}$ & {$[X, Y]_{22 k}$} \\
$k=1,2, \ldots, n_{21}$ & $k=1,2, \ldots, n_{22}$ \\
\hline
\end{tabular}

Keterangan :

$A_{1}=$ Intensitas Penilaian Formatif Per Pokok Bahasan

$A_{2}=$ Intensitas Penilaian Formatif Konvensional (Keseluruhan)

$X=$ Skor kemampuan awal Kalkulus mahasiswa

$Y=$ Skor hasil belajar Kalkulus mahasiswa 
Populasi dalam penelitian ini adalah seluruh mahasiswa Strata satu (S1) Kelompok Reguler peserta matakuliah Kalkulus Integral pada Program Studi Pendidikan Matematika, Fakultas Teknik \& MIPA (FTMIPA), Universitas Indraprasta PGRI (UNINDRA) yang terdaftar pada semester genap tahun akademik 2009/2010. Teknik sampling dilakukan dengan multi stage sampling, sebanyak 3 (tiga) stage (tahap), yaitu: tahap pertama memilih kelompok belajar, tahap kedua memilih rombongan belajar (kelas), dan tahap ketiga memilih subjek penelitian (mahasiswa). Sampel dalam penelitian ini diambil dari rombongan belajar yang terpilih sebagai sampel, baik pada kelas kontrol maupun kelas eksperimen dengan karakteristik mahasiswa yang relatif homogen. Mengingat populasi penelitian adalah mahasiswa yang memiliki karakteristik yang hampir sama (homogen), maka besarnya sampel penelitian tidak harus banyak. Ukuran atau besar sampel yang penting cukup untuk memenuhi kriteria persyaratan analisis statistik baik secara deskriptif maupun inferensial. Farouk dan Djaali (2005: 37) mengatakan, "Makin seragam populasi itu, makin kecil sampel yang dapat diambil. Apabila populasi itu seragam sempurna (completely homogeneous), maka satu satuan elementer saja dari seluruh populasi itu sudah cukup reprsentatif untuk diteliti." Selanjutnya, Roscoe dalam Sekaran (2006: 160) mengatakan bahwa, untuk penelitian eksperimen yang menggunakan kelompok eksperimen dan kontrol, maka jumlah anggota sampel untuk masing-masing kelompok antara $10 \mathrm{~s} / \mathrm{d} 20$. Untuk itu dalam penelitian ini peneliti menetapkan banyak atau ukuran sampel penelitian sebanyak 40 mahasiswa dengan rincian masing-masing kelompok penelitian 20 orang.

Analisis inferensial untuk pengujian hipotesis penelitian menggunakan statistik parametrik dengan teknik analisis kovarian (ANAKOVA) sederhana satu jalur. Untuk itu sebelum dilakukan analisis inferensial untuk pengujian hipotesis penelitian terlebih dahulu perlu dilakukan uji prasyarat analisis meliputi: uji normalitas, uji homogenitas, uji kelinearan, uji keberartian regresi kovariat terhadap variabel terikat, dan uji kesejajaran regresi. Analisis inferensial dilakukan dengan tujuan untuk menguji perbedaan rerata simpangan (adjusted mean) atau perbedaan intercept dengan 2 (dua) kelompok sampel. Model analisis analisis kovarian (ANAKOVA) sederhana satu arah, digunakan untuk menguji perbedaan tentang parameter rerata hasil belajar Kalkulus untuk semua kelompok mahasiswa yang dibentuk oleh intensitas penilaian formatif dengan mengontrol faktor kemampuan awal. Untuk ini, parameter yang diuji dalam analisis kovarian (ANAKOVA) yaitu perbedaan rerata simpangan (adjusted means) atau perbedaan konstanta dari regresi homogen. Hipotesis yang diuji dalam penelitian ini yaitu tentang Pengaruh Faktor Intensitas Penilaian Formatif terhadap Hasil Belajar Kalkulus dengan Mengontrol Kemampuan Awal Mahasiswa. Untuk menguji hipotesis ini, model regresi homogen yang diuji yaitu: $Y_{i j k}=\mu+A_{i}+X+\varepsilon_{i j}$, dimana:

$Y_{i j k}=$ menyatakan nilai observasi responden ke-k dalam sel $(i, j)$

$\mu=$ menyatakan parameter konstanta secara keseluruhan

$A_{i}=$ menyatakan parameter pengaruh tingkat atau perlakuan ke-i dari faktor intensitas penilaian formatif $(A)$

$X=$ skor sebuah variabel bebas atau kovariat tunggal

$\varepsilon_{i j}=$ menyatakan suatu kesalahan random

\section{HASIL PENELITIAN DAN PEMBAHASAN}

\section{Hasil Analisis Deskriptif}

Berikut ini disajikan hasil analisis deskripsi data mengenai skor hasil belajar Kalkulus kelompok eksperimen, kemampuan awal Kalkulus kelompok eksperimen, hasil belajar Kalkulus kelompok kontrol, dan kemampuan awal Kalkulus kelompok kontrol. 
Data lengkap rangkuman skor hasil belajar Kalkulus dan kemampuan awal Kalkulus untuk kedua kelompok dapat dilihat pada berikut.

Tabel 2. Skor Kemampuan Awal dan Hasil Belajar Kalkulus Mahasiswa antara Kelompok Eksperimen dan Kelompok Kontrol

Keterangan:

\begin{tabular}{|l|c|c|c|c|}
\hline \multirow{2}{*}{$\begin{array}{l}\text { Ukuran- } \\
\text { Ukuran } \\
\text { Deskriptif }\end{array}$} & \multicolumn{4}{|c|}{$A$} \\
\cline { 2 - 5 } & $X_{i}$ & $Y_{i}$ & $X_{i}$ & $Y_{i}$ \\
\hline$n$ & 20 & 20 & 20 & 20 \\
\hline $\bar{X} / \bar{Y}$ & 74,45 & 83,80 & 57,75 & 66,95 \\
\hline$s$ & 10,35 & 5,25 & 16,16 & 6,19 \\
\hline Min & 46 & 76 & 27 & 54 \\
\hline Max & 88 & 93 & 82 & 76 \\
\hline
\end{tabular}

$A=$ Intensitas penilaian formatif

$A_{l}=$ Intensitas Penilaian Formatif Per Pokok Bahasan

$A_{2}=$ Intensitas Penilaian Formatif Konvensional

$X=$ Kemampuan awal Kalkulus Mahasiswa

$Y=$ Hasil Belajar Kalkulus Mahasiswa

\section{Hasil Pengujian Prasyarat Analisis}

\section{a. Uji Normalitas}

Hasil analisis dan pengujian normalitas dengan teknik Lillifors diperoleh hasil seperti dalam tabel 3. dan 4. berikut.

Tabel. 3. Hasil Pengujian Normalitas

Data Hasil Belajar Kalkulus $\left(Y_{i j}\right)$

\begin{tabular}{|c|c|c|c|c|}
\hline Kelpk & $\mathrm{n}$ & $\mathrm{L}_{\mathrm{o}}$ & $\mathrm{Lt}$ & Simpulan Asal Populasi \\
\hline$A_{l}$ & 20 & 0,167 & 0,190 & Berdistribusi normal \\
\hline$A_{2}$ & 20 & 0,133 & 0,190 & Berdistribusi normal \\
\hline
\end{tabular}

Tabel. 4. Hasil Pengujian Normalitas

Data Kemampuan Awal Kalkulus $\left(X_{i j}\right)$

\begin{tabular}{|c|c|c|c|c|}
\hline Kelpk & $\mathrm{N}$ & $\mathrm{L}_{\mathrm{o}}$ & $\mathrm{Lt}$ & Simpulan Asal Populasi \\
\hline$A_{l}$ & 20 & 0,121 & 0,190 & Berdistribusi normal \\
\hline$A_{2}$ & 20 & 0,076 & 0,190 & Berdistribusi normal \\
\hline
\end{tabular}

\section{b. Uji Homogenitas}

Hasil analisis dan pengujian homogenitas dengan Levene's Test diperoleh hasil nilai $\mathrm{F}=2,361$ dengan nilai Sig. $=0,133>\alpha$; sehingga $\mathrm{H}_{0}$ diterima, dan dapat disimpulkan bahwa antara kelompok data kelompok $A_{1}$ (eksperimen) dan kelompok $A_{2}$ (kontrol) memiliki varians yang sama atau homogen.

\section{c. Uji Linearitas}

Dari analisis dan pengujian kelinearan regresi kovariat $(X)$ terhadap variabel takbebas $(Y)$ diperoleh nilai $\mathrm{F}=1,117$ dengan nilai sig. $=0,437>\alpha$; sehingga disimpulkan bahwa bahwa model regresi pengaruh kemampuan awal Kalkulus $(X)$ terhadap hasil belajar Kalkulus $(Y)$ berpola linear. 


\section{d. Uji Keberartian Pengaruh Regresi}

Hasil analisis dan pengujian keberartian koefisien regresi pengaruh kovariat (X) terhadap variabel tak-bebas (Y)

diperoleh nilaia $\mathrm{F}=30,368$ dengan nilai sig. $=0,000<\alpha$, sehingga disimpulkan bahwa variabel kovariat (kemampuan awal) mempunyai pengaruh yang signifikan terhadap variabel terikat (hasil belajar Kalkulus).

\section{e. Uji Kesejajaran Garis Regresi}

Hasil analisis dan pengujian kesejajan garis regresi diperoleh nilai $F=2,303$ dengan nilai sig. $=0,138>\alpha$, sehingga disimpulkan bahwa tidak ada perbedaan kemiringan garis regresi (slopes) yang signifikan dari semua faktor sel atau antara kelompok eksperimen dengan kelompok kontrol. Oleh karenanya dapat dinyatakan bahwa kedua garis regresi dari setiap faktor sel yang terbentuk oleh faktor intensitas penilaian formatif memiliki kemiringan atau slope yang homogen/sejajar.

Karena syarat-syarat yang terkait dengan statistika parametrik analisis kovarian (ANKOVA) seperti di atas telah terpenuhi, maka untuk selanjutnya analisis inferensial dalam rangka pengujian hipotesis penelitian menggunakan teknik statistik analisis kovarian (ANKOVA) atau uji homogenous slopes.

\section{Hasil Analisis Inferensial}

\section{a. Pengujian Hipotesis Utama}

Hipotesis yang diuji yaitu: "Terdapat perbedaan rerata hasil belajar Kalkulus antara kelompok eksperimen yang diberikan Intensitas Penilaian Formatif Per Pokok Bahasan dengan kelompok kontrol yang diberikan Intensitas Penilaian Formatif Konvensional, setelah mengendalikan pengaruh kemampuan awal Kalkulus mahasiswa." Hipotesis statistiknya ditulis: $\mathrm{H}_{0}: A_{\mathrm{i}}=0$ atau $\mu_{1}=\mu_{2}$ melawan H1: Bukan $\mathrm{H}_{0}$ atau $\mu_{1} \neq \mu_{2}$. Hasil analisis untuk pengujian hipotesis diperoleh hasil seperti tebel berikut.

Tabel 5. Hasil Analisis untuk Pengujian Hipotesis tentang Perbedaan Rerata $Y$ Menurut Faktor $A$ dengan Mengendalikan $X$

\begin{tabular}{|l|r|r|r|r|r|}
\hline & \multicolumn{1}{|c|}{$\mathrm{JK}_{\text {res }}$} & $\mathrm{Db}$ & \multicolumn{1}{c|}{$\mathrm{RJK}$} & \multicolumn{1}{c|}{$\mathrm{F}$} & \multicolumn{1}{c|}{ Sig. } \\
\hline Sumber Varian & 3120,699 & 2 & 1560,350 & 5,477 & 0,000 \\
Intercept & 5943,075 & 1 & 5943,075 & 226,537 & 0,000 \\
$X$ & 281,474 & 1 & 281,474 & 10,729 & 0,002 \\
$\boldsymbol{A}$ & 1303,368 & 1 & 1303,368 & 49,681 & 0,000 \\
Kesalahan & 970,676 & 37 & 26,234 & & \\
Total & 231347,000 & 40 & & & \\
Total Dikoreksi & 4091,375 & 39 & & & \\
\hline
\end{tabular}

Sumber: Data Primer diolah dengan SPSS versi 17.0

Berdasarkan tabel di atas, maka diperoleh untuk baris $A$ nilai $\mathrm{F}=49,681$ dengan nilai sig. $=0,000<0,05$; sehingga disimpulkan bahwa terdapat perbedaan rerata hasil belajar Kalkulus mahasiswa yang signifikan menurut faktor intensitas penilaian formatif dengan mengontrol kemampuan awal Kalkulus mahasiswa. Dengan demikian dapat disimpulkan terdapat pengaruh intensitas penilaian formatif terhadap hasil belajar Kalkulus setelah mengendalikan pengaruh kemampuan awal Kalkulus mahasiswa. 


\section{b. Pengujian Hipotesis Satu Pihak}

Hipotesis yang diuji yaitu: “ Diduga bahwa hasil belajar Kalkulus mahasiswa yang diberikan Intensitas Penilaian Formatif Per Pokok Bahasan lebih tinggi dari pada yang diberikan Intensitas Penilaian Formatif Konvensional, setelah mengendalikan pengaruh kemampuan awal Kalkulus mahasiswa." Hipotesis statistiknya ditulis: $\mathrm{H}_{0}$ : $\mu_{1} \leq \mu_{2}$ melawan $\mathrm{H}_{1}: \mu_{1}>\mu_{2}$.

Dari hasil analisis deskriptif di atas terlihat bahwa skor rerata hasil belajar Kalkulus pada kelompok mahasiswa yang diberikan Intensitas Penilaian Formatif Per Pokok Bahasan (kelompok eksperimen) adalah 80,05; sedangkan skor rerata hasil belajar Kalkulus pada kelompok mahasiswa yang diberikan Intensitas Penilaian Formatif Konvensional (kelompok kontrol) adalah 74,22. Di sini terlihat bahwa hasil belajar Kalkulus mahasiswa yang diberikan Intensitas Penilaian Formatif Per Pokok Bahasan lebih tinggi dibandingkan dengan mahasiswa yang diberikan Intensitas Penilaian Formatif Konvensional.

Selanjutnya, untuk menguji keberartian perbedaan hasil belajar Kalkulus antara kelompok eksperimen dengan kelompok kontrol tersebut dilakukan dengan teknik uji-t dan diperoleh hasil seperti tabel parameter estimasi berikut.

Tabel 6. Parameter Estimasi untuk Pengujian Hipotesis tentang Perbedaan Rerata $Y$ Menurut Faktor $A$ dengan Mengendalikan $X$ dengan Uji Satu Pihak

\begin{tabular}{|l|r|r|r|r|}
\hline \multicolumn{1}{|c|}{ Parameter } & \multicolumn{1}{c|}{$\mathrm{B}$} & Std. Error & \multicolumn{1}{c|}{$\mathrm{t}$} & \multicolumn{1}{c|}{ Sig. } \\
\hline Intercept & 55,369 & 3,717 & 14,898 & 0,000 \\
$X$ & 0,201 & 0,061 & 3,276 & 0,002 \\
{$[A=1]$} & 13,501 & 1,915 & 7,049 & 0,000 \\
{$[A=2]$} & $0(\mathrm{a})$ &. &. &. \\
\hline
\end{tabular}

Sumber: Data Primer diolah dengan SPSS versi 17.0

Berdasarkan tabel di atas, untuk. baris $[A=1]$ diperoleh nilai $\mathrm{t}=7,049$ dengan nilai sig. $0,000<0,05$, sehingga dsimpulkan bahwa hasil belajar Kalkulus mahasiswa yang diberikan Intensitas Penilaian Formatif Per Pokok Bahasan secara signifikan lebih tinggi dari pada yang diberikan Intensitas Penilaian Formatif Konvensional, setelah mengendalikan pengaruh kemampuan awal Kalkulus mahasiswa.

\section{Pembahasan}

Penelitian ini secara umum bertujuan untuk memperoleh gambaran lebih lengkap tentang pengaruh intensitas penilaian formatif terhadap hasil belajar Kalkulus dengan mengendalikan kemampuan awal Kalkulus mahasiswa. Hasil penelitian menunjukkan bahwa variabel intensitas penilaian formatif mempunyai pengaruh yang signifikan terhadap hasil belajar Kalkulus mahasiswa setelah mengendalikan kemampuan awal mahasiswa.

Penelitian ini berhasil menemukan bahwa hasil belajar Kalkulus mahasiswa yang diberikan Intensitas Penilaian Formatif Per Pokok Bahasan lebih tinggi dari pada mahasiswa yang diberikan Intensitas Penilaian Formatif Konvensional, setelah mengendalikan pengaruh kemampuan awal Kalkulus mahasiswa. Kesimpulan ini didukung pula oleh perolehan statistik deskriptif, yang menunjukkan rerata hasil belajar 
Kalkulus mahasiswa yang diberikan Intensitas Penilaian Formatif Per Pokok Bahasan sebesar 80,05 dan rerata hasil belajar mahasiswa yang diberikan Intensitas Penilaian Formatif Konvensional sebesar 74,22.

Dalam penelitian ini yang dimaksud hasil belajar Kalkulus yaitu hasil belajar Kalkulus integral. Kalkulus integral merupakan matakuliah yang menuntut pemahaman yang mendalam secara konseptual. Kalkulus integral merupakan kelanjutan dari matakuliah Kalkulus diferensial. Penguasaan konsep turunan sebagai materi utama dalam Kalkulus diferensial akan sangat berpengaruh terhadap hasil belajar Kalkulus integral. Penguasaan konsep turunan merupakan pengetahuan prasyarat yang harus dimiliki oleh mahasiswa sebelum mempelajari matakuliah Kalkulus integral. Oleh karenanya, pengaruh dari penguasaan pada konsep prasyarat tersebut harus dikontrol agar tidak menimbulkan kerancuan atau bias dalam penarikan kesimpulan penelitian. Pengusaan terhadap konsep pengetahuan prasyarat tersebut dalam penelitian ini disebut dengan kemampuan awal Kalkulus.

Pemberian intensitas penilaian formatif dimaksudkan untuk memberikan gambaran tentang pengaruh pelaksanaan penilaian formatif terhadap hasil belajar Kalkulus mahasiswa. Intensitas penilaian formatif yang dimaksud adalah (1) Intensitas Penilaian Formatif Per Pokok Bahasan, yaitu kekerapan penilaian formatif hasil belajar mahasiswa yang dilakukan setelah selesai setiap pokok bahasan, dan (2) Intensitas Penilaian Formatif Konvensional, yaitu kekerapan penilaian formatif hasil belajar mahasiswa yang dilakukan seperti yang berlangsung selama ini, yakni dilakukan setelah materi secara keseluruhan selesai. Black and Wiliam (1998) menyatakan, bahwa inovasi penilaian formatif merupakan salah satu aspek yang menentukan kualitas proses dan hasil pembelajaran di dalam kelas.

Kalkulus sebagai bagian dari matematika selalu berkenaan dengan ide-ide atau konsep-konsep abstrak yang tersusun secara hierarki dengan menggunakan penalaran deduktif. Pengajaran Kalkulus di perguruan tinggi tersusun berdasarkan materi-materi yang satu dengan lainnya saling berhubungan, artinya penguasaan terhadap materi yang satu akan mempengaruhi penguasaan terhadap materi berikutnya. Mengingat banyaknya cakupan yang perlu dibahas dalam matakuliah Kalkulus, maka untuk mendapatkan hasil terbaik setiap mahasiswa harus belajar dengan teratur dan sistematik. Latihan-latihan soal terstruktur dan sesuai pokok bahasan yang dipelajari akan menjadi langkah terbaik untuk mendapatkan hasil belajar yang optimal dalam matakuliah ini.

Intensitas Penilaian Formatif Per Pokok Bahasan memberi kesempatan mahasiswa untuk dinilai tingkat pemahamannya dalam belajar Kalkulus yang dilakukan sedikit demi sedikit secara bertahap tetapi sering. Kegiatan penilaian formatif semacam ini diharapkan dapat memudahkan mahasiswa dalam mempelajari materi pembelajaran. Penialain Formatif Per Pokok Bahasan ini pun memberi kesempatan pada mahasiswa untuk langsung mengikuti tes atau penilaian tidak lama setelah materi diajarkan, sehingga diharapkan materi tersebut masih terekam dengan baik dalam otak. Dalam penilaian formatif per pokok bahasan, mahasiswa dapat segera diketahui ketuntasan belajarnya (mastery) untuk setiap bagian materi yang telah dipelajarinya, sehingga apabila belum dicapai tingkat ketuntasan belajarnya dapat segera dilakukan remedial.

Intensitas Penilaian Formatif Konvensional (Keseluruhan) dilakukan setelah seluruh materi Kalkulus yang ditetapkan dalam kurikulum selesai diajarkan semuanya. Kondisi ini memberi kesempatan mahasiswa untuk belajar sekaligus dalam menghadapi tes untuk penilaian formatif. Hal ini mengandung makna, bahwa materi yang harus dipelajari sangat banyak, dan mungkin sebagian sudah agak terlupakan karena waktu belajarnya sudah berlalu cukup lama. Fenomena ini akan dirasakan menjadi beban dan kesulitan tersendiri terutama untuk mahasiswa yang inisiatif belajarnya kurang. Dengan 
penilaian formatif konvensional, tingkat ketuntasan belajar (mastery) mahasiswa baru diketahui setelah semua materi Kalkulus selesai diajarkan. Setelah dilakukan penilaian, kemudian dosen memilah-milah /menganasilis materi mana yang sudah dikuasai (tuntas) dan materi mana yang belum tuntas untuk setiap mahasiswa. Berdasarkan hasil analisis atau pemilahan tersebut selanjutnya dosen melakukan remedial terhadap materi yang belum dikuasai oleh mahasiswa.

Berdasarkan penjelasan tersebut, maka akan dapat dipahami bahwa secara keseluruhan pemberian Intensitas Penilaian Formatif Per Pokok Bahasan akan lebih efektif dari pada pemberian Intensitas Penilaian Formatif Konvensional dalam proses pembelajaran Kalkulus. Hal ini sesuai dengan yang diungkapkan oleh Black dan Wiliam (1998) yang menyatakan bahwa, hasil penelitian pada mahasiswa di beberapa negara menunjukkan bahwa dengan melakukan inovasi penilaian formatif yang lebih sering memberikan dampak pada hasil belajar yang signifikan. Kondisi inilah yang menyebabkan hasil belajar Kalkulus mahasiswa yang diberikan Intensitas Penilaian Formatif Per Pokok Bahasan lebih tinggi dari pada yang diberikan Intensitas Penilaian Formatif Konvensional.

\section{PENUTUP}

\section{Kesimpulan}

Terdapat perbedaan hasil belajar Kalkulus antara mahasiswa yang diberikan Intensitas Penilaian Formatif per Pokok Bahasan dan Intensitas Penilaian Keseluruhan (Konvensional), setelah mengendalikan pengaruh kemampuan awal Kalkulus mahasiswa. Dalam hal ini, hasil belajar Kalkulus mahasiswa yang diberikan Intensitas Penilaian Formatif per Pokok Bahasan lebih tinggi dari pada yang diberikan Intensitas Penilaian Formatif Konvensional (Keseluruhan), setelah mengendalikan pengaruh kemampuan awal Kalkulus mahasiswa. Hal ini mengindikasikan, terdapat pengaruh intensitas penilaian formatif terhadap hasil belajar Kalkulus dengan mengendalikan kemampuan awal Kalkulus mahasiswa.

\section{Implikasi}

Berdasarkan kesimpulan penelitian, ditemukan bahwa intensitas penilaian formatif merupakan faktor yang sangat penting dalam meningkatkan hasil belajar Kalkulus mahasiswa. Penggunaan intensitas penilaian formatif yang tepat akan berpengaruh secara signifikan terhadap hasil belajar mahasiswa, khususnya dalam pembelajaran matakuliah Kalkulus. Oleh karena itu, hasil penelitian ini dapat memberikan implikasi dalam peningkatan kualitas proses pembelajaran dan hasil belajar Kalkulus.

Hasil penelitian menyimpulkan terdapat pengaruh intensitas penilaian formatif terhadap hasil belajar Kalkulus dengan mengendalikan kemampuan awal Kalkulus mahasiswa. Dalam hal ini, penelitian menemukan bahwa hasil belajar Kalkulus mahasiswa yang diberikan Intensitas Penilaian Formatif Per Pokok Bahasan lebih tinggi dari pada hasil belajar Kalkulus mahasiswa yang diberikan Intensitas Penilaian Formatif Konvensional (Keseluruhan), setelah mengendalikan pengaruh kemampuan awal Kalkulus mahasiswa. Berdasarkan temuan ini, maka dalam rangka meningkatkan kualitas hasil belajar Kalkulus mahasiswa dapat dilakukan dengan cara para dosen menerapkan Intensitas Penilaian Formatif Per Pokok Bahasan dalam mengevaluasi proses pembelajaran mahasiswa.

Intensitas Penilaian Formatif per Pokok Bbahasan adalah suatu intensitas penilaian formatif yang digunakan oleh dosen untuk mendapatkan informasi dan pengambilan kesimpulan tentang hasil belajar mahasiswa yang dilakukan secara bertahap 
per pokok bahasan atau bagian per bagian sesuai dengan materi (pokok bahasan) yang telah dipelajari di dalam kelas. Untuk dapat terlaksananya kegiatan Intensitas Penilaian Formatif Per Pokok Bahasan dalam proses pembelajarn di kelas oleh dosen, maka direkomendasikan hendaknya manajemen satuan program studi atau perguruan tinggi mengkondisikan dan memfasilitasi suasana pembelajaran yang memungkinkan. Upayaupaya yang dapat dilakukan untuk merangsang dan memotivasi para dosen dapat melaksanakan kegiatan Intensitas Penilaian Formatif Per Pokok Bahasan dalam proses pembelajaran di antaranya sebagai berikut. (1) Perlu dilakukan kegiatan workshop atau sejenisnya dalam rangka meningkatkan dan menyamakan persepsi tentang bentuk-bentuk intensitas penilaian formatif, khususnya pemahaman tentang Intensitas Penilaian Formatif Per Pokok Bahasan oleh para dosen dan manajemen satuan program studi. (2) Pada awal semester setiap dosen dianjurkan untuk membuat rencana program pembelajaran (RPP) atau satuan acara perkulihan (SAP) yang di dalamnya memuat secara rinci tentang rencana kegiatan penilaian formatif yang dilakukan per pokok bahasan selama proses pembelajaran di dalam kelas. (3) RPP atau SAP yang memuat secara rinci tentang pelaksanaan kegiatan Penilaian Formatif Per Pokok Bahasan diverifikasi dan disyahkan oleh manajemen satuan program studi serta disosialisasikan pada mahasiswa peserta kuliah. (4) Manajemen satuan program studi agar menyiapkan anggaran untuk keperluan pengadaan kertas ujian dan bahan-bahan atau sarana ujian lainnya. (5) Manajemen satuan program studi agar menyiapkan sarana untuk memfasilitasi para dosen melaksanakan kegiatan penilaian formatif dan melakukan tindak lanjuta untuk menangani mahasiswa yang belum tuntas atau belum mencapai mastery berdasarkan hasil penilain.

Dengan dilakukannya upaya-upaya tersebut diharapkan para dosen akan lebih memahami akan pentingnya dan tata cara melaksanakan Penilaian Formatif Per Pokok Bahasan. Selain itu juga diharapkan para dosen akan termotivasi dan terbiasa melaksanakan kegiatan Penilaian Formatif Per Pokok Bahasan untuk mengevaluasi efektifitan proses pembelajaran. Pada akhirnya, diharapkan agar mutu hasil belajar Kalkulus menjadi meningkat, sesuai dengan yang diharapkan.

\section{Saran}

Berdasarkan kesimpulan dan implikasi di atas, dapat disampaikan saran sebagai berikut. (1) Intensitas Penilaian Formatif Per Pokok Bahasan dapat dijadikan sebagai pendekatan penilaian formatif inovatif dalam pembelajaran matakuliah Kalkulus, karena dalam penelitian ini terbukti bahwa mahasiswa secara keseluruhan mendapatkan kemudahan dalam memahami materi yang lebih baik. (2) Perlu adanya koordinasi dan kesepakatan antara para dosen pengampu matakuliah Kalkulus untuk menemukan format yang tepat dalam menentukan intensitas penilaian formatif yang tepat dalam proses pembelajaran agar diperolah hasil belajar Kalkulus mahasiswa yang optimal. (3) Penelitian ini baru dilakukan pada satu matakuliah yaitu matakuliah Kalkulus dan dilakukan pada satu perguruan tinggi yaitu pada Universitas Indraprasta PGRI di Jakarta. Untuk itu, disarankan model penelitian ini dapat direflikasikan untuk matakuliahmatakuliah lainnya maupun pada lembaga-lembaga pendidikan tinggi lainnya untuk mendapatkan generalisasi yang lebih luas. (4) Ranah hasil belajar yang diteliti dalam penelitian ini sebagai dampak dari penggunaan inovasi penilaian formatif adalah ranah kognitif; untuk ini kiranya dapat dilakukan penelitian lanjutan untuk meneliti pengaruh inovasi penilaian formatif semacam ini terhaap hasil belajar ranah afektif (sikap dan perilaku) dan ranah psikomotor. 


\section{DAFTAR PUSTAKA}

Al-Kadiri, Nizar. "Kemampuan Awal siswa". Edukasi Kompasiana, 2009. http://edukasi.kompasiana.com/2009/12/22/kemampuan-awal-siswa/ (diakses 13 Agustus 2010).

Black, Paul and Dylan Wiliam. "Inside the Black Box: Raising Standards Through Classroom Assessment". Phi Delta Kappa International Journal, 1998. http://blog.discoveryeducation.com/assessment/files/2009/02/blackbox_article.pdf (akses: 19 Januari 2011)

Buchori, Mochtar. Pendidikan Antisipatoris. Yogyakarta: Penerbit Kanisius, 2001.

Dimyati dan Mudjiono. Belajar dan Pembelajaran. Jakarta: PT. Rineka Cipta, 2006.

Djaali dan Puji Muljono. Pengukuran dalam Bidang Pendidikan. Jakarta: Grasindo, 2008.

Sholeh, Munawar. Politik Pendidikan Membangun Sumber Daya Bangsa dengan Peningkatan Kualitas Pendidikan. Jakarta: Institute for Public Education, 2005.

Ibrahim Abdullah, Suparman. "Matematika Sebagai Dasar Semua Ilmu," Makalah. Orasi Ilmiah Wisuda Sarjana XVIII UNINDRA PGRI. Jakarta: Unindra, 2006.

Muhammad, Farouk dan Djaali. Metodologi Penelitian Sosial. Jakarta: Restu Agung, 2005.

Pidarta, Made. Landasan Kependidikan Stimulus Ilmu Pendidikan Bercorak Indonesia. Jakarta: PT. Rineka Cipta, 2007.

Purwanto, Heri, Gina Indriani, dan Erlina Dayanti. Kalkulus. Jakarta: PT. Ercontara Rajawali, 2005.

Purwanto, M. Ngalim. Psikologi Pendidikan. Bandung: Remaja Rosdakarya, 2007.

Rasyad, Aminudin. Teori Belajar dan Pembelajaran. Jakarta: UHAMKA Press \& Yayasan PEP-Ex 8, 2003.

Rose, Colin and Malcolm J. Nicholl. Accelerated Learning for The $21^{\text {ST }}$ Century. New York: Delacorte Press, 1997.

Sekaran, Uma. Research Methods for Business buku 2, terjemahan Kwan Men Yon. Jakarta: Penerbit Salemba Empat, 2006.

Shaffat, Idris. Optimized Learning Strategy Pendekatan Teoritis dan Praktis Meraih Keberhasilan Belajar. Jakarta: Prestasi Pustaka Publisher, 2009.

Supardi U.S. dan Leonard. 2010. Menakar keberhasilan pelaksanaan kebijakan sekolah gratis di DKI Jakarta. Jurnal Penelitian Kebijakan Pendidikan LIPI, 3(8), 268-285.

Surapranata, Sumarna. Panduan Penulisan Tes Tertulis - Implementasi Kurikulum 2004. Bandung: Remaja Rosdakarya, 2007.

Stewart, James. Kalkulus Jilid 1, terjemahan I Nyoman Susila dan Hendra Gunawan. Jakarta: Gramedia, 2001.

Suyatno. Menjelajah Pembelajaran Inovatif . Sidoarjo: Masmedia Buana Pustaka, 2009.

Walija. "Wacana Pengantar Setengah Abad FKIP UHAMKA Sajadah Panjang Perjuangan Pendidikan." Cakrawala Pendidikan, editor: Walija dan Bahrul Hasibuan. Jakarta: Uhamka Press, 2007.

Wena, Made. Strategi Pembelajaran Inovatif Kontemporer. Jakarta: PT. Bumi Aksara, 2009.

Zainul, Asmawi dan Noehi Nasution. Penilaian Hasil Belajar. Jakarta: PAU-PPAI Universitas Terbuka, 2005. 